\title{
Tropical Viticulture Diagnosis in the North and Northwest Fluminense
}

\author{
Jaomara Nascimento da Silva ${ }^{1}$, Niraldo José Ponciano ${ }^{1}$, Paulo Marcelo Souza ${ }^{1}$, Claudio Luiz Melo de Souza ${ }^{2}$, \\ Leandro Hespanhol Viana ${ }^{1}$, Marcelo Geraldo de Morais Silva ${ }^{3}$, Marcela Brite Alfaiate ${ }^{1}$, \\ Carla Roberta Ferraz Carvalho Bila ${ }^{1}$, Rogério Figueiredo Daher ${ }^{1} \&$ Geraldo de Amaral Gravina ${ }^{1}$ \\ ${ }^{1}$ State University of Northern Fluminense, Campos dos Goytacazes, Rio de Janeiro, Brazil \\ ${ }^{2}$ Candido Mendes Institute, Candido Mendes University, Campos dos Goytacazes, Rio de Janeiro, Brazil \\ ${ }^{3}$ Fluminense Federal Institute, Cambuci, Rio de Janeiro, Brazil \\ Correspondence: Jaomara Nascimento da Silva, State University of Northern Fluminense, Campos dos \\ Goytacazes, Rio de Janeiro, Brazil. E-mail: jaomarasilva@gmail.com
}

$\begin{array}{ll}\text { Received: February 12, } 2021 & \text { Accepted: March 19, } 2021 \quad \text { Online Published: April 15, } 2021 \\ \text { doi:10.5539/jas.v13n5p171 } & \text { URL: https://doi.org/10.5539/jas.v13n5p171 }\end{array}$

\begin{abstract}
Viticulture has proved to be an alternative for farmers in the northen and northwestern Rio de Janeiro State; however, the activity is still very recent and requires the development of agronomic and managerial techniques. Therefore, the objective of this work was to diagnose the production areas and the characteristics inherent to the inner and outer environment of this farming enterprise. It was observed that the grape-growing farms predominate in an average area of 1 hectare, with productivity between 20 and $25 \mathrm{t} / \mathrm{ha}$, with offer in the harvest and in the off-season. The inner points are stronger than the weak ones, and can be adjusted with the joint execution of the viticulturists allied to the opportunities, such as agrotourism and the diversification of available cultivars that allow a greater offer of the product and minimize the inherent threats observed, such as climatic variations and the shortage of skilled labor. These identified points may indicate competitiveness strategies for the wine market in the studied regions.
\end{abstract}

Keywords: grape, productive chain, SOWT matrix, Vitis labrusca

\section{Introduction}

The wine sector is one of the most important for the Brazilian agricultural economy, as it provides livelihood for a number of small grape-growing farms. Although present in many States and regions, it is especially significant in Southern Brazil where a large part of the production is intended for agribusiness of juice and wine (Baldin et al., 2018). The southern region of Brazil stands out as the largest producer of grapes, for the production of wine, while in the Southeast and Northeast regions, the production of grapes for fresh consumption predominates (Mello, 2016).

Among the grape-producing states in the southeastern region, Rio de Janeiro has an area of 17 hectares (IBGE, 2018) ranking the 11th position among the grape-producing states in Brazil. Although it presents a very small production, it is observed the importance of this sector for the generation of income for small farmers in the north and northwestern Fluminense regions (Pommer et al., 2009).

The grape production in the State of Rio de Janeiro is much lower than that in areas in São Paulo State and with a smaller grape production area in the southeastern region. Nevertheless, it is likely that its grape is a factor that boosts local economies particulary because it is in expansion in the northern and northwestern Fluminense Region. It should be observed that the latter region is among the regions of Rio de Janeiro with the worst rates of economic development, with a poorly diversified agricultural sector.

The Fluminense viticulture is still an incipient activity. It has been disseminated through scientific research and by farmers who have been seeking for alternatives in this agricultural business. According to Pommer et al. (2009) the northern region of Rio de Janeiro has conditions to establish itself as a hub for table grapes in the State, with more than two harvests a year. It is possible to find information about the behavior of this crop in these regions in studies by Almeida et al. (2017), Silva et al. (2017), Deus et al. (2016), among others.

The viticulture chain is relevant due to the diversification of the local productive matrix, the added value, the generation of income and jobs as well as the increase in the Gross Domestic Product (GDP) of the municipalities 
involved. Because those crops are at their beginning, a diagnosis of the inner and outter points can serve as a reference regarding the development of the Fluminense viticulture and a guide to agricultural policies. In addition, management tools can be used within rural properties as a strategy to increase productivity (Parré, Bankutti, \& Zanmaria, 2011).

According to Lopes et al. (2018) these tools can optimize the activity as a whole, both in the administration and in the management of the rural property, resulting in increased profitability and return. The adequate management can provide winegrowers with improvements in their socioeconomic conditions, strategic decisions and advances in the productive activity.

In the agricultural sector, SWOT analysis is used to assess the strategic position of projects. In India, the tool was used to analyze the agricultural sector in terms of capacity to meet further food security requirements (Parveen \& Nain, 2013). In relation to the Fluminense viticulture, which is still in recent development, it can be a tool for the analysis of the inner and outter environment that can characterize the development of the activity.

The knowledge of the inner and outter factors linked to the development of this activity in a sustainable way is relevant to make the productive units more competitive. Thus, the objective of this work was to analyze viticulture in the North and Northwest Fluminense Regions, identifying the strengths and weaknesses, the potential and threats that can influence their development.

\section{Method}

\subsection{Study Area}

The study area is located in the north and northwest Regions of the State of Rio de Janeiro (Figure 1). In the Northern Fluminense the following municipalities are found: Campos dos Goytacazes, Carapebus, Cardoso Moreira and São Fidelis. And the following municipalities are found in the northwest Region: Bom Jesus do Itabapoana, Cambuci, Italva, São José de Ubá and Varre Sai. These municipalities were selected taking into account the fact that they are the grape-producing municipalities in the regions, adding to the lack of economic information on production costs, the lack of data on the behavior of grape prices and analyzes of economic viability viticulture in development in these regions.

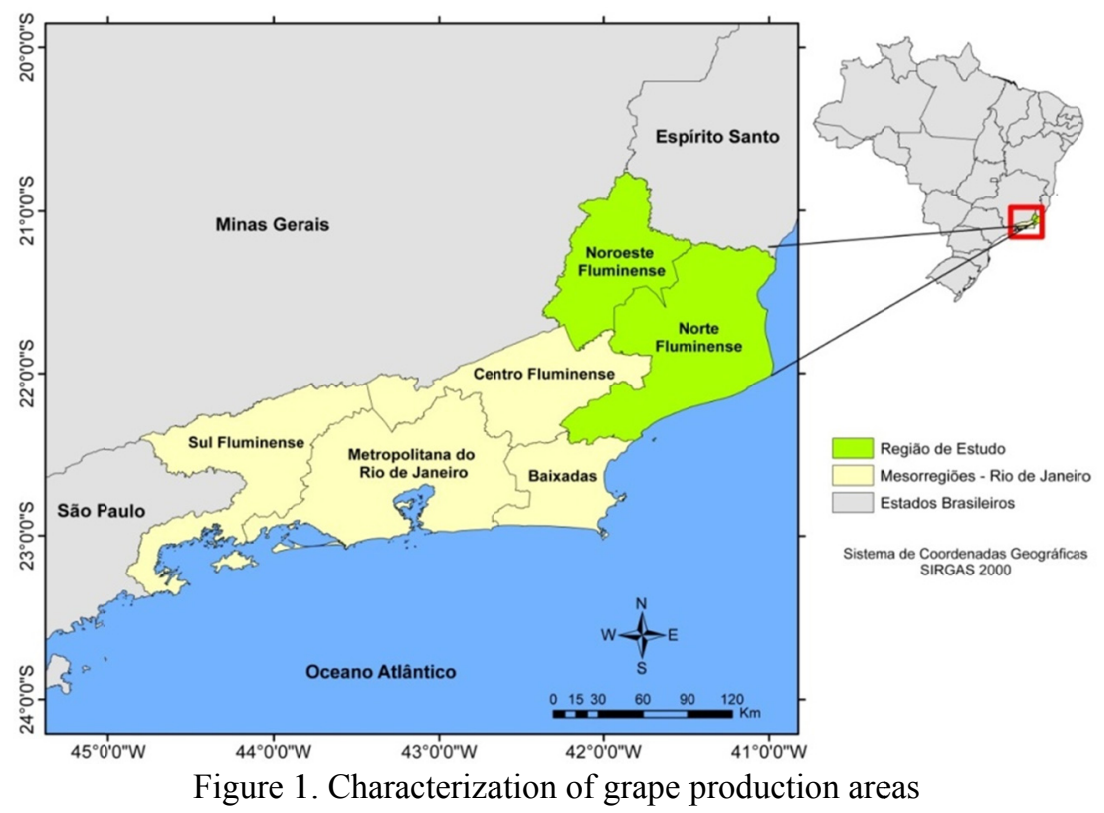

\subsection{Data Collection}

Data were collected by means of semi-structured interviews, through field research, from April 2017 to May 2018. The interviews were conducted directly with all winegrowers in the regions, considering the total number of 16 producers, and grape cultivation area already implemented in the regions in this period. Firstly, through these interviews, the following data were collected: location of grape production areas, size of production areas and average productivity. 


\subsection{Data Analysis}

Following data collection, an organizational assessment tool denominated SWOT Matrix was applied, in order to observe the following variables: Strengths, Weaknesses, Opportunities and Threats. This analysis was carried out on two levels: in the outter and inner environments. The inner environment examines the strengths and weaknesses that need to be monitored constantly and can be controlled. The external environment, in turn, comprises changes that occur outside the organization, but which can affect its performance, being characterized by threats and opportunities.

After analyzing the outter and inner environments, companies can decide which competitive strategies should be used to achieve their competitive objective. Competitive strategies could be used to "exploit opportunities in the company's environment with the company's strength and neutralize threats in the company's environment, avoiding the company's weaknesses". This analysis can be the starting point in the identification and implementation of the most appropriate strategy for the wine business in the areas surveyed. Thus, this work allows the identification of a strategy that can explore the strengths of viticulture in Rio de Janeiro and eliminate or minimize, at least, weaknesses and the outter threats.

As a result, this matrix allows analyzing the strengths and weaknesses as perspectives that depend only on the viticulturist and on his or her productive system and the opportunities and threats, which, in turn, do not depend on the action of the producer and on the response of his or her productive systems, but on outter factors.

The results obtained from the interviews were organized into tables with data in relative frequency, as well as the studies by Biassio and Crespo Silva (2015); Sarmento (2017); Nascimento Mendes, Dos Anjos, and Raphael (2018), and Schneider, Zilli, and Vieira (2017).

\section{Results and Discussion}

\subsection{Characterization of the Grape Production Areas}

The diagnosis carried out in the field allowed to identify nine producing municipalities, among them, the municipality of Bom Jesus do Itabapoana as the largest in production area $(7 \mathrm{ha})$ in the Northwest Region and Cardoso Moreira in the North Region (4 ha), while São José de Ubá had the largest number of producers per municipality (Table 1). Also, the producing areas were distributed in the regions. Small and medium farmers predominate in both regions, with a strong presence of family labor. Similar data for viticulture were found in other regions by Anzanello (2012) in Rio Grande do Sul and Cappello, Spósito, and Osaki (2017) in the Northwest of São Paulo State.

Table 1. Grape production units and number of winegrowers in northern and northwestern Rio de Janeiro State

\begin{tabular}{lllll}
\hline Municipalities & Area (ha) & $(\%)$ & *No. & $(\%)$ \\
\hline Nothwest Region & 11.5 & 67.65 & 11 & 68.75 \\
Bom Jesus do Itabapoana & 7 & 41.18 & 1 & 6.25 \\
São José de Ubá & 2 & 11.76 & 4 & 25 \\
Varre Sai & 1 & 5.88 & 3 & 18.75 \\
Cambuci & 1 & 5.88 & 2 & 12.5 \\
Italva & 0.5 & 2.94 & 1 & 6.25 \\
North Region & 5.5 & $32, .35$ & 5 & 31.25 \\
Cardoso Moreira & 4 & 23.53 & 1 & 6.25 \\
São Fidélis & 1 & 5.88 & 2 & 12.5 \\
Campos dos Goytacazes & 0.25 & 1.47 & 1 & 6.25 \\
Carapebus & 0.25 & 1.47 & 1 & 6.25 \\
Total & 17 & 100 & 16 & 100 \\
\hline
\end{tabular}

Note. *No.: Number of grapegrowers/municipalities.

In $88 \%$ of the farms, the grape cultivation occupies an area of less than 1 ha. This reduced size is due to the amount that was subsidized by the Frutificar Program, and the other producers that invested on their own since they consider the activity as a novelty in the regions. Similar data were observed by Cappello et al. (2017) and Duarte (2013). It should be observed that, in order to expand the areas, more capital and greater availability of labor and guarantees for placing the product on the market are needed. 
Productivity per hectare is between 20 and $25 \mathrm{t} / \mathrm{ha} /$ year, for 10 respondents $(62.5 \%)$. Different productivity may be achieved depending on the variety, driving system and technological level and year of production. In Rio Grande do Sul, Anzanello (2012) found that the average yield was 9.6 t/ha, and Cappello et al. (2017) in the State of São Paulo observed 14 t/ha in the harvest, and 10 t/ha in the off-season in the region of Campinas. The comparison between the average of these leading traditional grape regions in the country showed that the local edaphoclimatic conditions, as well as, the appropriate management for cultivation has provided a very attractive productivity.

\subsection{Analysis of the SWOT (Strengths, Weaknesses, Opportunities, Threats) Matrix}

The strengths and weaknesses are related to the capacity and influence of the factors that can contribute or harm the grape production systems found in the regions. While, the opportunities were defined as aspects that are important to encourage the productive areas until the flow of the production, and the threats were listed as aspects that represent risks to the maintenance of the production systems (Table 2).

Table 2. Factors that influence the competitiveness of grape production and trade in the North and Northwest Fluminense Regions

\begin{tabular}{ll}
\hline \multicolumn{1}{c}{ SWOT MATRIX } \\
\hline STRENGTHS: & WEAKNESSES: \\
1. Favorable edaphoclimatic conditions & 1. Lack of producer's organization \\
2. More than one harvest per year & 2. Little experience in viticulture \\
3. Proximity to consumers & 3. Market shortages by producers \\
4. Trade in the property & 4. Little administrative knowledge \\
5. Strengthening of the family workforce & \\
6. Agricultural diversification & \\
7. Possibility of local trade & \\
\hline & EXTERNAL ENVIRONMENT \\
\hline OPPORTUNITIES: & THREATS: \\
1. Fruiting Program & 1. High investment cost \\
2. Agrotourism & 2. Low water availability \\
3. Availability of variety diversity & 3. Absence of agricultural policies \\
5. Research development & 4. Shortage of skilled labor \\
6. Few intermediaries & 5. Few courses and field days \\
7. Additional income source & \\
\hline
\end{tabular}

\subsubsection{Strengths}

Among the strengths, the edaphoclimatic conditions of the regions promote the development of grape cultivation, such as solar radiation, temperature, relative humidity, precipitation and soil fertility. Associated with these conditions, management practices adapted to local conditions, such as scheduled pruning, use of irrigation and plant regulators, enable the grape producer to obtain more than one harvest throughout the year. In addition, the phenological cycle and thermal needs of the grapevine are similar to those found in the State of São Paulo.

The proximity of the farmers to the main consumer, in addition to providing a trade with other agricultural products within the properties, has strengthened viticulture in the regions. This trade on the property narrows the relationship between the producer and the consumer, and generally results in better prices for the producer, since the product does not pass through different agents in the chain up to retail. These data differ from the observations by Alves, Tonin, and Carrer (2013) in Paraná, where producers cannot classify the product and are unable to offer a large volume without the presence of an intermediary, with a trade that generally results in lower prices for the producers.

\subsubsection{Weaknesses}

One weaknesses in the chain is the little experience in viticulture. As it is still an incipient activity, many producers do not know the behavior of the grapevine over the year, and throughout the development of the crop 
they need to adapt the management combinied to the local edaphoclimatic conditions, and identify the physiological and nutritional demand of this fruit.

Technical agents also point out the lack of organization of the farmers as a major weakness in almost every rural sector, and it is not characteristic only of grape producers. In particular, it can be considered that at the stage of viticulture development, the existence of associations and cooperatives would strengthen the chain and the development of culture in the regions. Most municipalities in Rio de Janeiro have family farming with low levels of modernization, in particular, the North and Northwest regions show family farming with relatively low rates of use of the technologies, considered in the analysis carried out by De Souza, Souza, and Fereira Neto (2018). In view of this weakness, it is necessary to emphasize, the search for local organization can be an alternative for strengthening winegrowers, constituting an instrument for competitiveness. The formation of associations and cooperatives is an important tool for social, political and economic organization (Costa, Junior, Gomes, \& Silva, 2015).

\subsubsection{Opportunities}

Agricultural policies can be arrangements of instruments that stimulate agricultural production. In this context, the Frutificar Program is an agricultural policy that developed the cultivation of grapes in the regions, since it encouraged and subsidized $62.5 \%$ of the interviewed wine growers. Costa, Tarsitano, and Conceição (2012) observed that the majority of winegrowers invested in the grape, through the National Program for Strengthening Family Agriculture (PRONAF) in the municipality of Jales (SP).

There is also a possibility of local vineyards to provide the "sale" of the tourist territory of the regions, also highlighting the sustainability of the regional grape. Agrotourism has been promoted by the consumption of grapes and by-products within the crop. Some producers report having received 30 people per month in the field in harvest months. Viticulture can even trigger a greater dissemination of tourism, not only by motivating wine tourism but also focusing on other attractions in the regions, as also reported by Sarmento (2017).

The good performance of winegrowing in different regions of the country is linked to the great variability in the genetic material used. There are more than 120 cultivars of Vitis vinifera and more than 40 cultivars of American grapes, including Vitis labrusca varieties (Camargo, Tonietto, \& Hoffmann, 2011). The diversity of cultivars is another promising variable that favors viticulture in Rio de Janeiro, considering that the different characteristics of cultivars can aid ompetitiveness in this productive sector. In the distribution of cultivated varieties there are nine varieties, among which stands out the cultivation of 'Niagara Rosada', followed by cultivars, BRS Vitória, BRS Isabel Precoce, BRS Isis, Bordô, and others in smaller areas. This diversity allows a greater variety in the offer of the grape, giving the producer and consumer more options in the wine market, such as seedless grapes, and grapes that can be used for the production of wines, juices and jams, increasing the farm's gross revenue, corroborating with Mello (2017).

The insertion of grape cultivation not only diversifies agricultural production in the regions, as observed in some properties with only an economic activity as a source of income, such as dairy farming, tomato and coffee farming but also allows to balance the income when a product has a drop in its value. This diversification is of great importance in terms of social reproduction strategy, as it guarantees yields in seasonal periods of production, minimizing the risks of having a single activity.

The expansion of viticulture to vitiviniculture mainly in northwestern Rio de Janeiro is a factor that boosts the local economies, since it is a region that has the lowest economic development rates in the State. In addition to the opportunities, the agents reported the maintenance of rural people in the region since throughout the crop, there is a considerable demand for labor, similar to what is reported by Pommer et al. (2009), being an important ameliorator of social problems in these regions.

Among the nine institutions that support local agriculture, six had the knowledge of grape production, but they only assist in commercialization through the National School Food Program (PNAE). Although, for some producers, the price paid for this program has already been advantageous, they stressed that it has suffered a reduction and delay in the payment, corroborating with Agapto et al. (2012). It seems that some farmers have the potential to participate in this process; however, these factors may discourage them.

\subsubsection{Threats}

In contrast, it is known that agriculture is vulnerable to the effects that the climate changes has on hydrological balances and natural resources. The interference of water shortage in the pruning and harvest seasons, observed by some producers, affected the possibility of more than one harvest per year. Regardless of being natural or 
anthropogenic, it is necessary to seek strategies mainly for small farmers as because of their dependende on agricultural production, will suffer the greatest impacts (Mertz et al., 2009; Deressa, Hassan, \& Ringler, 2011).

The high investment value for the implementation is also a threat to the expansion of new vineyards. With the incentive of Frutificar (Agricultural development program of the State of Rio de Janeiro that aims to finance fruit-growing projects in the State), many producers had subsidies to start, the production; however, it is currently active only for maintenance. In addition to this failure in the operation of Frutificar, the lack of agricultural policies aimed at the development of viticulture in the regions is highlighted.

There is a lack of technical assistance for the management, the investment and the risk analysis in these regions. Thus, knowledge about administrative processes may provide advances in the production of the activity and added-value to the final product. There is also little skilled labor to guide them in cultivation techniques, such as pruning, phytosanitary management and harvesting, as found by Costa et al. (2012) in Jales, SP. Due to the high cost and the increasing difficulty in the availability of labor, winegrowers need to adjust themselves by intensifying the search for more productive cultivars and training systems for vines, as observed by Pedro Junior, Hernandes, and Moura (2018).

\section{Conclusion}

The edaphoclimatic conditions and the possibility of more than one harvest are points that contribute to the diversification of the productive matrix, job creation and sustainable development in the regions. The Frutificar Program and the development of studies are the outer factors that promoted the performance of viticulture in Rio de Janeiro. This demonstrates that the strengths and opportunities of this activity indicate the great potential to establish competitive advantages for the regions.

There was a lack of specialized technical assistance, management training for local producers, and water issues, which need to be adjusted for the better performance of the grapevine and the continuity of the recent development of the activity in the regions.

There was a need for strategies for the production and organization of producers, in order to better explore the strengths and opportunities, and keep production the best as possible in the face of unfavorable conditions, both in terms of climate changes and the market.

Finally, the present study can support further works on the scenario of the development of viticulture in the regions of Rio de Janeiro, and to contribute to the exploration of the points of competitiveness presented in the study.

\section{References}

Agapto, J. P., Borsatto, R. S., Esquerdo, V. D. S., \& Bergamasco, S. M. P. (2012). Avaliação do Programa de Aquisição de Alimentos (PAA) em Campina do Monte Alegre, estado de São Paulo, a partir da percepção dos agricultores. Informações Econômicas, 42, 13-21.

Almeida, L. V. B., Figueiredo, F. A. M. M. A., Deus, B. C., Viana, L. H., Ferraz, T. M., Martins, A. O., ... Campostrini, E. (2017). Plastic covering film can reduce midday depression photosynthesis of field-grown tropical grapevine in high photosynthetic photon flux. Acta Horticulturae, 1, 255-262. https://doi.org/ 10.17660/actahortic.2017.1157.36

Alves, A. F., Tonin, J. M., \& Carrer, M. J. (2013). Assimetria de transmissão de preço na comercialização da uva fina de mesa no Paraná: 1997 a 2011. Revista de Economia e Sociologia Rural, 51, 479-498. https://doi.org/ $10.1590 / \mathrm{S} 0103-20032013000300004$

Anzanello, R. (2012). Caracterização da viticultura no Rio Grande do Sul por meio da análise dos dados do Cadastro Vitícola. Pesquisa Agropecuária Gaúcha, 18, 67-73.

Baldin, T., da Silveira, A. G., Talgatti, M., Santini, E. J., \& Cardoso Marchiori, J. N. (2018). Grape rachis in composites manufacturing. Brazilian Journal of Agricultural Sciences, 13, 1-6. https://doi.org/10.5039/ agraria.v13i1a5503

Biassio, A., \& Crespo Silva, I. (2015). Análise SWOT como ferramenta para avaliação da agrobiodiversidade em sistemas tradicionais de produção nos municípios de Antonina e Morretes/PR. Scientia Agraria, 16, 71-76. https://doi.org/10.5380/rsa.v16i2.41051

Camargo, U. A., Tonietto, J., \& Hoffmann, A. (2011). Progressos na viticultura brasileira. Revista Brasileira de Fruticultura, SP, 144-149. https://doi.org/10.1590/S0100-29452011000500017 
Cappello, F. P., Spósito, M. B., \& Osaki, M. (2017). Production costs and profitability of Niagara Rosada Table grape grown in different regions of São Paulo State. Revista Brasileira de Fruticultura, 39 , e-774. https://doi.org/10.1590/0100-29452017774

Costa, A. B., Junior, A., Gomes, P. C., \& Silva, M. G. (2015). As cooperativas de agricultura familiar e o mercado de compras governamentais em Minas Gerais. Revista de Economia e Sociologia Rural, 53, 109-26. https://doi.org/10.1590/1234-56781806-9479005301006

Costa, V. T., Tarsitano, M. A. A., \& Conceição, M. A. F. (2012). Caracterização social e tecnológica da produção de uvas para mesa em pequenas propriedades rurais da região de Jales-SP. Revista Brasileira de Fruticultura, 34, 766-773. https://doi.org/10.1590/S0100-29452012000300016

De Souza, H. M., De Souza, P. M., \& Ferreira Neto, J. A. (2018). Heterogeneidade da agricultura familiar: uma análise dos municípios fluminenses a partir de aspectos da modernização. Revista de Economia e Agronegócio, 16(2), 202-225. https://doi.org/10.25070/rea.v16i2.549

Deressa, T. T., Hassan, R. M., \& Ringler, C. (2011). Perception of and adaptation to climate change by farmers in the Nile basin of Ethiopia. Journal of Agricultural Science, 149, 23-31. https://doi.org/10.1017/ S0021859610000687

Deus, B. C. D. S. D., Figueiredo, F. A. M. M. D., Almeida, L. V. B. D., Ferraz, T. M., Martins, A. O., Rodrigues, W. P. V. L. H., ... Campostrini, E. (2016). Photosynthetic capacity of 'Niagara Rosada' grapes grown under transparent plastic covering. Ciência Rural, 46, 950-956. https://doi.org/10.1590/0103-8478cr20150400

Duarte, V. N. (2013). Estudo da Cadeia Produtiva do Vinho em Santa Catarina: Características e Estágio Atual. Evidência-Ciência e Biotecnologia, 13, 41-56. Retrieved from https://portalperiodicos.unoesc.edu.br/eviden cia/article/view/2472

IBGE (Instituto Brasileiro de Geografia e Estatística). (2018). Levantamento sistemático da Produção Agrícola. Retrieved November 20, 2018, from http:/www.sidra.ibge.gov.br/bda/tabela/listabl.asp? $\mathrm{z}=\mathrm{t} \& \mathrm{c}=1613$

Lopes, M. A., Reis, E. M. B., Demeu, F. A., Mesquita, A. A., Rocha, A. G. F., Pelegrini, D. F., ... Teixeira Junior, F. E. P. (2018). Uso de ferramentas de gestão na atividade leiteira: um estudo multicascos em Uberlândia, MG. Revista Agropecuária Técnica, 39, 73-86. https://doi.org/10.25066/agrotec.v39i1.34302

Mello, L. M. R. (2016). Desempenho da vitivinicultura brasileira em 2015 (Comunicado Técnico 191, p. 5). Bento Gonçalves, Embrapa Uva e Vinho. Retrieved from https:/www.embrapa.br/uva-e-vinho/ busca-de-noticias/-/noticia/9952204/artigo-desempenho-da-vitivinicultura-brasileira-em-2015

Mello, L. M. R.(2017). Panorama da produção de uvas e vinhos no Brasil (Comunicado Técnico 207, p. 11) Bento Gonçalves, Embrapa Uva e Vinho. Retrieved from https://ainfo.cnptia.embrapa.br/digital/bitstream/ item/187913/1/Comu nicado-Tecnico-207.pdf

Mertz, O., Mbow, C., Reenberg, A., \& Diouf, A. (2009). Farmers' Perceptions of Climate Change and Agricultural Adaptation Strategies in Rural Sahel. Environmental Management, 43, 804-816. https://doi.org/ 10.1007/s00267-008-9197-0

Nascimento Mendes, L. N., Dos Anjos, I. L. J., \& Raphael, G. A. (2018). Agricultural marketing in the syb-middle São Francisco Valley: the importance of the Juazeiro-BA producers market. Brazilian Journal of Development, 4, 3451-3477.

Parré, J. L., Bankutti, S. M. C., \& Zanmaria, N. A. (2011). Perfil socioeconômico de produtores de leite da região sudoeste do Paraná: um estudo a partir de diferentes níveis de produtividade. Revista de Economia e Agronegócio, 9, 275-300. https://doi.org/10.25070/rea.v9i2.187

Parveen, K., \& Nain, M. S. (2013). Agricultura na Índia: Uma análise SWOT. Indian Journal Applied Research, 3, 4-6. https://doi.org/10.15373/2249555X/JULY2013/2

Pedro Júnior, M. J., Hernandes, J. L., \& Moura, M. F. (2018). Performance of juice and wine grape cultivars in different training systems. Revista Brasileira de Fruticultura, 40, e-055. https://doi.org/10.1590/0100-2945 2018055

Pommer, C. V., Mendes, L. S., Hespanhol-Viana, L., \& Bressan-Smith, R. (2009). Potencial climático para a produção de uvas em Campos dos Goytacazes, região norte fluminense. Revista Brasileira de Fruticultura, 31, 1076-1083. https://doi.org/10.1590/S0100-29452009000400022

Sarmento, M. B. (2017). Diagnóstico da Vitivinicultura na Campanha Gaúcha: Uma análise SWOT. Agropampa: Revista de Gestão do Agronegócio, 1, 65-85. 
Schneider, M. D., Zilli, J. C., \& Vieira, A. C. P. (2017). Diagnóstico mercadológico: um estudo em uma vinícola nos Vales da Uva Goethe-Santa Catarina. Revista da Universidade Vale do Rio Verde, 15, 759-768. https://doi.org/10.5892/ruvrd.v15i2.3132

Silva, J. R., Patterson, A. E., Rodrigues, W. P., Campostrini, E., \& Griffin, K. L. (2017). Photosynthetic acclimation to elevated $\mathrm{CO} 2$ combined with partial rootzone drying results in improved water use efficiency, drought tolerance and leaf carbon balance of grapevines (Vitis labrusca). Environmental and Experimental Botany, 134, 82-95. https://doi.org/10.1016/j.envexpbot.2016.11.007

\section{Appendix}

\section{Data collection}

\begin{tabular}{|c|c|c|c|c|}
\hline & ha & $\mathrm{N}$ & $\%$ & t/ha \\
\hline \multicolumn{5}{|l|}{ Grape production units } \\
\hline \multicolumn{5}{|l|}{ Number of winegrowers } \\
\hline \multicolumn{5}{|l|}{ Productivity } \\
\hline Points & $\mathrm{S}$ & $\mathrm{W}$ & $\mathrm{O}$ & $\mathrm{T}$ \\
\hline \multicolumn{5}{|c|}{ Favorable edaphoclimatic conditions } \\
\hline \multicolumn{5}{|c|}{ More than one harvest per year } \\
\hline \multicolumn{5}{|l|}{ Proximity to consumers } \\
\hline \multicolumn{5}{|l|}{ Trade in the property } \\
\hline \multicolumn{5}{|c|}{ Strengthening of the family workforce } \\
\hline \multicolumn{5}{|l|}{ Agricultural diversification } \\
\hline \multicolumn{5}{|l|}{ Possibility of local trade } \\
\hline \multicolumn{5}{|l|}{ Lack of producer's organization } \\
\hline \multicolumn{5}{|l|}{ Little experience in viticulture } \\
\hline \multicolumn{5}{|l|}{ Market shortages by producers } \\
\hline \multicolumn{5}{|l|}{ Little administrative knowledge } \\
\hline \multicolumn{5}{|l|}{ Fruiting Program } \\
\hline \multicolumn{5}{|l|}{ Agrotourism } \\
\hline \multicolumn{5}{|l|}{ Availability of variety diversity } \\
\hline \multicolumn{5}{|l|}{ Research development } \\
\hline \multicolumn{5}{|l|}{ Few intermediaries } \\
\hline \multicolumn{5}{|l|}{ Additional income source } \\
\hline \multicolumn{5}{|l|}{ High investment cost } \\
\hline \multicolumn{5}{|l|}{ Low water availability } \\
\hline \multicolumn{5}{|l|}{ Absence of agricultural policies } \\
\hline \multicolumn{5}{|l|}{ Shortage of skilled labor } \\
\hline Few courses and field days & & & & \\
\hline
\end{tabular}

\section{Copyrights}

Copyright for this article is retained by the author(s), with first publication rights granted to the journal.

This is an open-access article distributed under the terms and conditions of the Creative Commons Attribution license (http://creativecommons.org/licenses/by/4.0/). 